\title{
Atypical lesions in relapsed leprosy
}

\author{
Theisla Kely Azevedo Raiol ${ }^{1}$ \\ Patrícia de Barros Guimarães ${ }^{1}$ \\ Daniela Mayumi Takano ${ }^{1}$
}

\author{
Solange Emanuelle Volpato ${ }^{1}$ \\ Maria Luciana Andrade de Almeida Lopes ${ }^{1}$ \\ Jaci Maria Santana ${ }^{1}$
}

DOI: http://dx.doi.org/10.1590/abd1806-4841.20142989

\begin{abstract}
Relapsed cases of leprosy are not common in patients treated regularly with the recommended polychemotherapeutical schemes. Relapses must be readily identified and distinguished from reactions. This article reports a clinical case of relapse in leprosy, with atypical and exuberant skin changes in patient treated for eleven years with a paucibacillary scheme.
\end{abstract}

Keywords: Case reports; Leprosy, multibacillary; Recurrence

\section{INTRODUCTION}

Among the strategies for control of Hansen's disease, an early diagnosis of cases and their adequate treatment with recommended polychemotherapy (PCT) regimens are paramount as recommended by World Health Organization (WHO). ${ }^{1}$ Leprosy relapse cases are rare in patients treated regularly with the recommended polychemotherapeutical schemes. Usually relapses occur in a period greater than five years after the cure. ${ }^{1}$ Differential diagnosis between reaction and relapse must be based on the association of clinical and laboratory exams., ${ }^{1,2}$ This article describes a clinical case of relapse, with atypical and exuberant cutaneous presentations.

\section{CASE REPORT}

A 49-year-old female patient, originally from Gravatá-PE, complained about burning pain in feet, forearms and hands, with onset three years ago. She referred a previous treatment for Hansen's disease 11 years ago, during six months. In the last three years, she has used several drugs for the treatment of hansenic reaction. According to a notification sheet, the patient had been classified under the tuberculoid clinical form, presenting negative bacilloscopy and discharged after being considered cured, at the end of six months of treatment (in 2002).

At the current physical examination, erythematous, infiltrative and fibrotic lesions, which followed a linear pattern on forearms, hands and feet, drew atten- tion (Figure 1, 2 and 3). She also presented madarosis on the full extension of her eyebrows, distal nail dystrophy in hands and feet, and foveolar lesion in the cervical region. Bacilloscopy was then requested, with the following result: IB: 5.75; IM: Whole Bacilli: 60; Several clumps. A histopathological exam of the erythemato-fibrotic lesions was also requested, which evidenced a lymphohistiocytic, periadnexal, perineural and perivascular inflammatory infiltrate, vacuolated macrophages containing clumps, besides the presence of bacilli in Ziehl-Neelsen staining (Figure 4). Based on the clinical history and complementary exams, multibacillary polychemotherapy was started and the prednisone dose was increased to $40 \mathrm{mg} /$ day (patient was taking $20 \mathrm{mg} /$ day). After one month, she already showed great improvement of lesions on the upper limbs and of pain symptoms in hands and feet (Figure 5). However, the clinical improvement of feet lesions was not as pronounced as in the upper limbs (Figure 6).

\section{DISCUSSION}

In leprosy, relapse should be taken into account when, after completion of adequate treatment and discharge after the patient is considered cured, signs and symptoms of disease activity reappear., ${ }^{1,2}$ The patient had been initially classified (11 years ago) under the tuberculoid clinical form, being treated and receiving a clean bill of health. Afterwards it progressed with new skin lesions.

Financial funding: None

Hospital Otávio de Freitas (HOF) - Recife (PE), Brazil. 


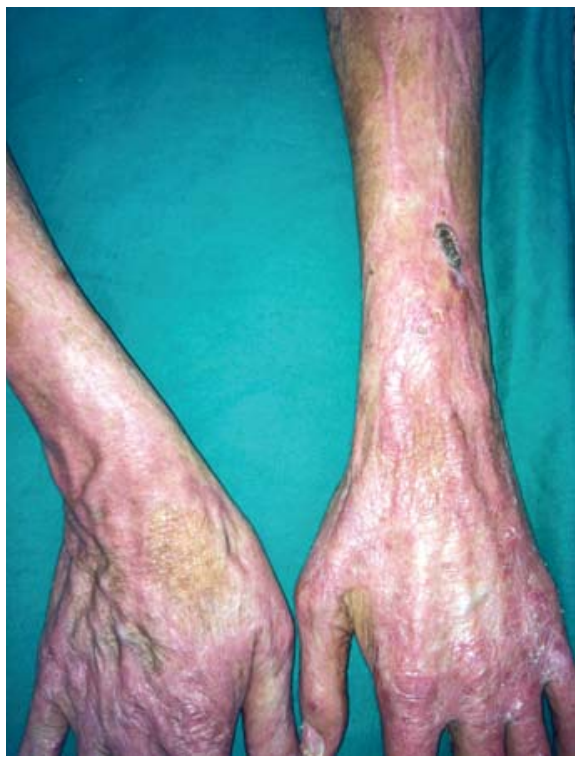

Figure 1:

Infiltrative linear lesions on forearms and hands. Atypical presentation pattern in dimorphous-virchowian Hansen's disease

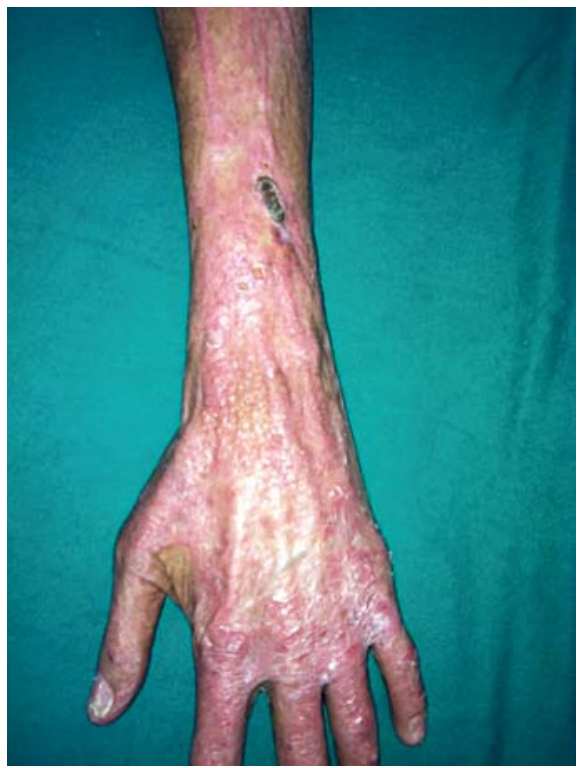

FIGURE 2:

Infiltrated lesions of atypical pattern in Hansen's disease

Patients that present worsening of lesions after completion of treatment must be directed to referral services for evaluation. ${ }^{1}$

Sometimes the distinction between relapse and reaction is difficult, and it is based mainly on clinical aspects: cutaneous lesions related to reactions usually start earlier, during or even up to the first year after the PCT; on the other hand the lesions that suggest relapse happen later, appearing even many years after treatment (on average, after a period of 5 years). ${ }^{1,2}$ As opposed to lesions arising from relapse, response to corticoids is remarkable in reactional cases. ${ }^{1}$

According to the Ministry of Health, the criteria for diagnosing relapse for paucibacillary (PB) cases are: the patient who, after receiving a clean bill of

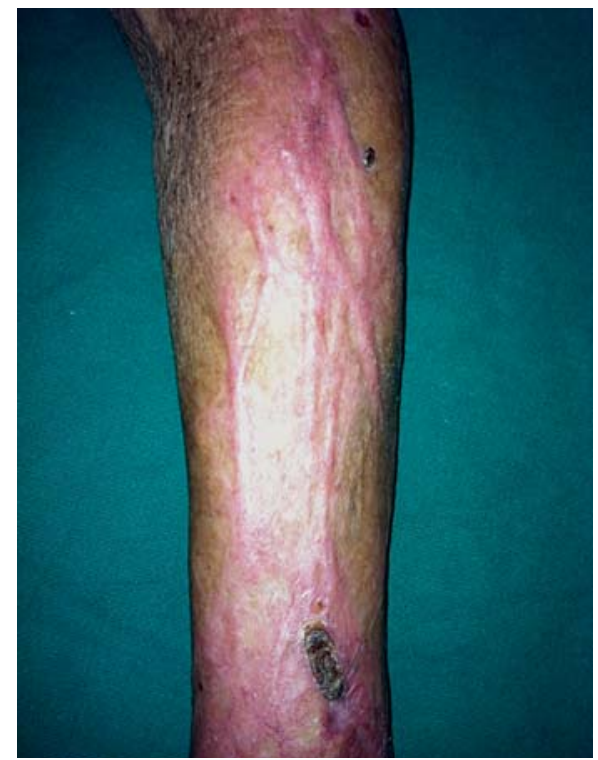

FIGURE 3:

Infiltrated

lesions of atypical pattern in Hansen's disease

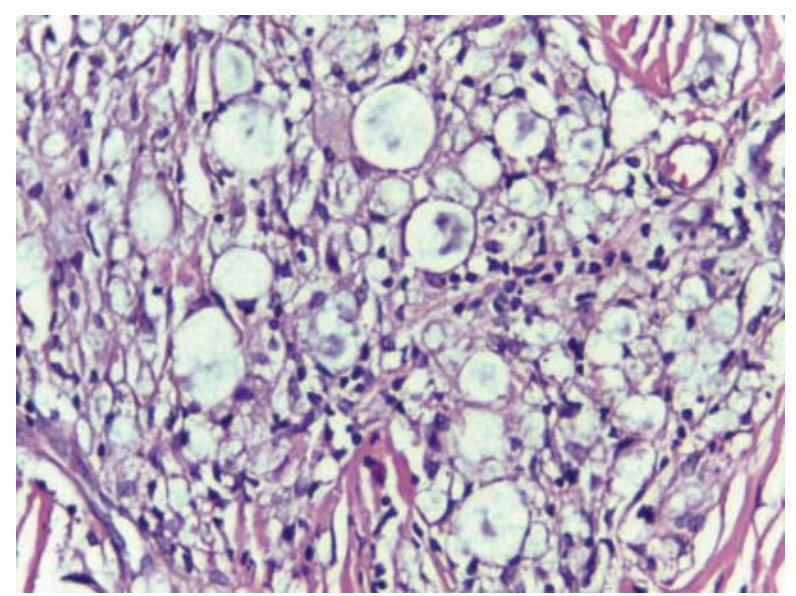

FIGURE 4: Histopathological aspect of erythematous-infiltrate lesion, evidencing a perineural and perivascular lymphohistiocytic inflammatory infiltrate

health, presents pain in nerve pathways, with new lesions and/or exacerbation of previous lesions which do not respond to treatment with corticosteroids, for at least 90 (ninety) days; and patients with late reactional outbreaks, usually five years after being considered healed. ${ }^{1}$

For multibacillary cases (MB): the patient who, after receiving a clean bill of health, presents cutaneous lesions and/or exacerbation of old lesions, new neurological changes which do not respond to treatment with thalidomide and/or corticosteroid in recommended doses and timeframes, positive bacilloscopy and compatible clinical picture with patients never treated before; patients with late reactional outbreaks, usually five years after being considered cured. 


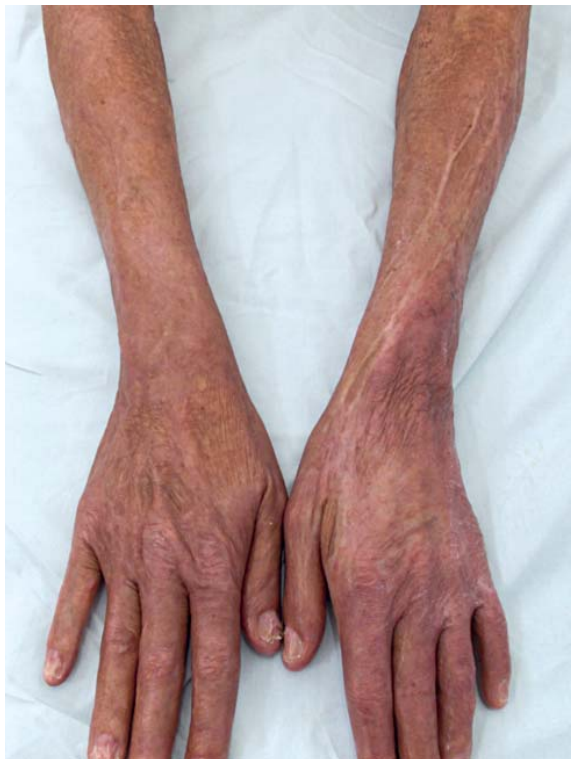

FigURE 5:

Clinical improvement of infiltrative lesions, after introduction of multibacillary polychemotherapy

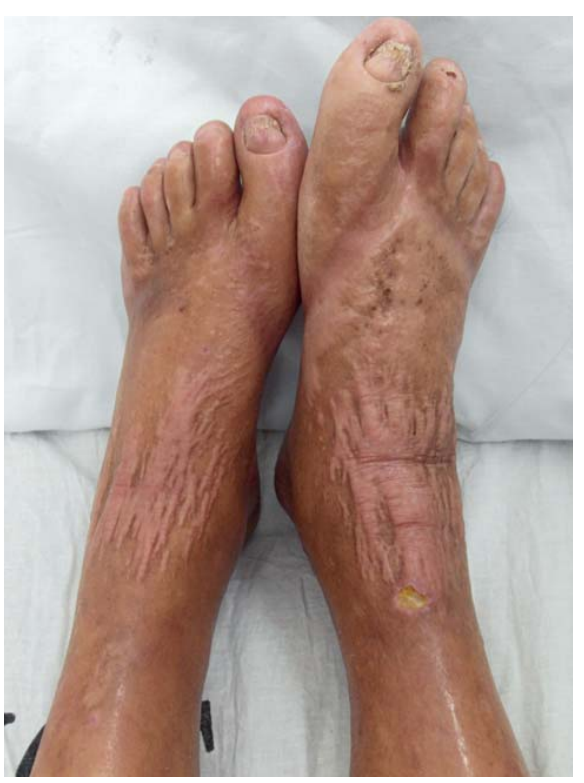

FigURE 6:

Aspect of

linear and erythematous-

fibrotic lesions, before the treatment. Even 30 days after the introduction of polychemotherapy, there was no remarkable improvement of feet lesions, as occurred with forearms

In a study carried out by Brito and colleagues in 2005, in an endemic Hansen's disease region, the clinical criterion was the most used to decide for a new relapse treatment, followed by bacilloscopy. ${ }^{3}$

The relapses of Hansen's disease may occur due to various factors, such as: immunosuppression, persistence of bacillum, resistance to drugs, inadequate or irregular therapeutics, or wrong initial classification. ${ }^{2,4}$
Relapses associated with drug resistance have been reported since the early 1960 's, chiefly related to long-term use of dapsone. ${ }^{5,6}$ Reports of resistance to rifampicin (RIF) are less common, although not less important, since RIF is the main drug of the PCT scheme, with a high bactericide effect. ${ }^{5}$

Diniz and Col. Evidenced, in a retrospective cohort study (2009), that the magnitude of hansenosis relapse is low, and more frequent between the dimorphous and virchowian forms. ${ }^{7}$

The patient was classified under the current clinical form, as dimorphous-virchowian, due to the presence of foveolar lesion (characteristic of the dimorphous form) and diffuse and infiltrative lesions with positive bacilloscopy (characteristic of the virchowian form). ${ }^{8}$ She was also diagnosed as carrier of type 1 hansenic reaction, with neuritis in upper and lower limbs (hands and feet).

It was considered a relapse due to the late onset of new lesions and no response to anti-reactional drugs. When a new treatment was established, with a multibacillary scheme, there was clinical improvement of lesions, and with the increased prednisone dose there was improvement of neuritic pain. Probably the patient was classified in an inadequate way eleven years ago (in the $1^{\text {st }}$ treatment) and treated with an insufficient scheme for the complete eradication of the bacilli. This way, there was persistence of viable bacilli, which slowly multiplied for years, leading to the development of exuberant clinical lesions. There was no evidence of further exposure with nontreated communicants.

When a paucibacillary patient relapses as a multibacillary one, it is very probable that an error in classification occurred during the initial treatment. ${ }^{3}$

For Ximenes et al (2007) and Shetty et al (2005), patients that presented reactional episodes have greater probability of being treated as having a relapse. ${ }^{9,10}$

In spite of the attested efficacy of PCT/WHO schemes, surveillance of drug resistance must be carried out. To that end, the referral units must forward sample material of multibacillary cases with confirmed relapse to the national referral centers which perform this surveillance. ${ }^{1}$ 


\section{REFERENCES}

1. Portal.saude.gov.br [Internet]. Brasil. Ministério da Saúde. Secretaria de Vigilância em Saúde. Portaria $\mathrm{n}^{0} 3.125$, de 7 de Outubro de 2010. Aprova as Diretrizes para Vigilância, Atenção e Controle da hanseníase. [acesso 10 Mar 2013]. Disponível em: http://portal.saude.gov.br/portal/arquivos/pdf/portaria_n_3125_hanseniase_2010.pdf.

2. Teixeira LO, Silva CM, Akamatsu HT, Barreto JA, Soares CT. Neural relapse in multibacillary leprosy 6 years after end of treatment. An Bras Dermatol. 2012;87:310-3.

3. Brito MFM, Ximenes RAA, Gallo MEN. Retreatment of leprosy relapse. An Bras Dermatol. 2005;80:255-60.

4. Barreto JA, Goya F, Miranda RMC. Hanseníase dimorfa reativada: recidiva ou tratamento insuficiente em paciente imunologicamente suscetível. Hansen Int.2006;31:35-8.

5. Instituto Lauro de Souza Lima. Coordenadoria de Controle de Doenças. Secretaria de Estado da Saúde. Recidiva e resistência em hanseníase. Rev Saúde Pública 2011;:45:631-3

6. Oliveira MLW. A cura da hanseníase x Magnitude das recidivas. An Bras Drematol. 1997;72:63-9.

7. Diniz LM, Moreira MV, Puppin MA, de Oliveira ML. Retrospective study on leprosy relapse in the State of Espírito Santo. Rev Soc Bras Med Trop. 2009;42:420-4.

8. Opromolla DVA. Manifestações clínicas e reações. In: Opromolla DVA, editor. Noções de hansenologia. Bauru: Hospital Lauro de Souza Lima; 2000. p.51-7.

9. Ximenes RAA, Gallo MEN, Brito MFM. Retreatment in Leprosy: a case-control study. Rev Saude Publica. 2007;41:632-7.

10. Shetty VP, Wakade AV, Ghate SD, Pai VV, Ganapati RR, Antia NH. Clinical, histopathological and bacteriological study of 52 referral MB cases relapsing after MDT. Lepr Rev. 2005;76:241-52.
MAILING ADDRESS:

Theisla Kely Azevedo Raiol

Rua Aprígio Guimarães, s/n

Tejipió

50920640 - Recife - PE

Brazil

E-mail: tkraiol@hotmail.com

How to cite this article: Raiol TKA, Volpato SE, Guimarães PB, Lopes MLAA, Takano DM, Santana JM. Atypical lesions relapsed leprosy. An Bras Dermatol. 2014;89(5):808-11. 